\section{The natives were friendly}

Warwick Bray

The National Geographic Society: 100 Years of Adventure and Discovery. By C.D.B Bryan. Abrams, New York/Phaidon, Oxford: 1987. Pp.484. \$45, £35.

THE publication of this sumptuous, and thoroughly enjoyable, volume to celebrate 100 years of the National Geographic Society makes one realize how much its magazine has become a part of everyday life. Like many people, I first came across it at school, on wet afternoons when games were cancelled, though it was than all the photos of volcanoes or happy peasants, that excited our adolescent imaginations.

In later years disillusion set in. The photos were still magwere true - but they were the wrong facts. The bright and innocent world of the National Geographic bore little relationship to the world described by the wireless and the newspapers. With its winsome style, and lack of analysis, the magazine was beautiful but trivial, a sort of Reader's Digest with pictures. It was not until much later, by which time I was a professional archaeologist, that I appreciated how much serious research was financed by the Society. Now, with the recent launching of its excellent technical journal, National Geographic Research ( 76 years after the idea was first proposed), and the current policy of good commercial popularization of science, the Society has intellectually come of age and has got its priorities right.

Bryan's historical survey confirms the general accuracy of these impressions. He inter-
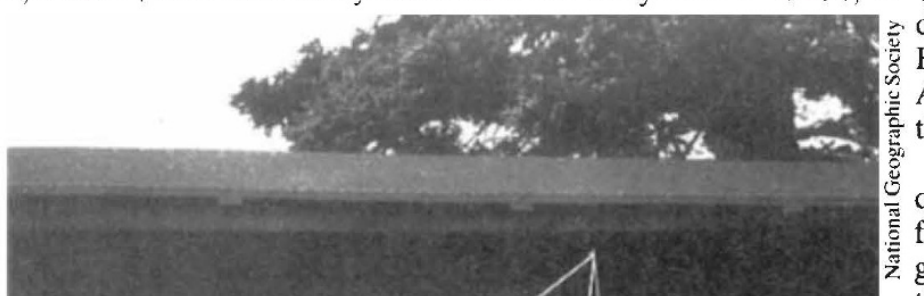

or the eruption of Mount St Helens in 1980 ) to the everyday details of a world that is disappearing. Today it gives a genuine shock to find a black-and-white photo (from 1896) of a Zulu bridal couple captioned "These people are of a dark bronze hue, and have good athletic fig. ures. They possess some excellent traits, but are horribly cruel when once they have

Age of innocence - "Dr and Mrs Bell demonstrate the lightness of both the inventor's tetrahedral structure and their hearts". Alexander Graham Bell became president of the National Geographic Society in 1898 on the death of its first president, his father-in-law Gardiner Greene Hubbard. the occasional glimpse of a nipple, rather nificent and the facts in the text

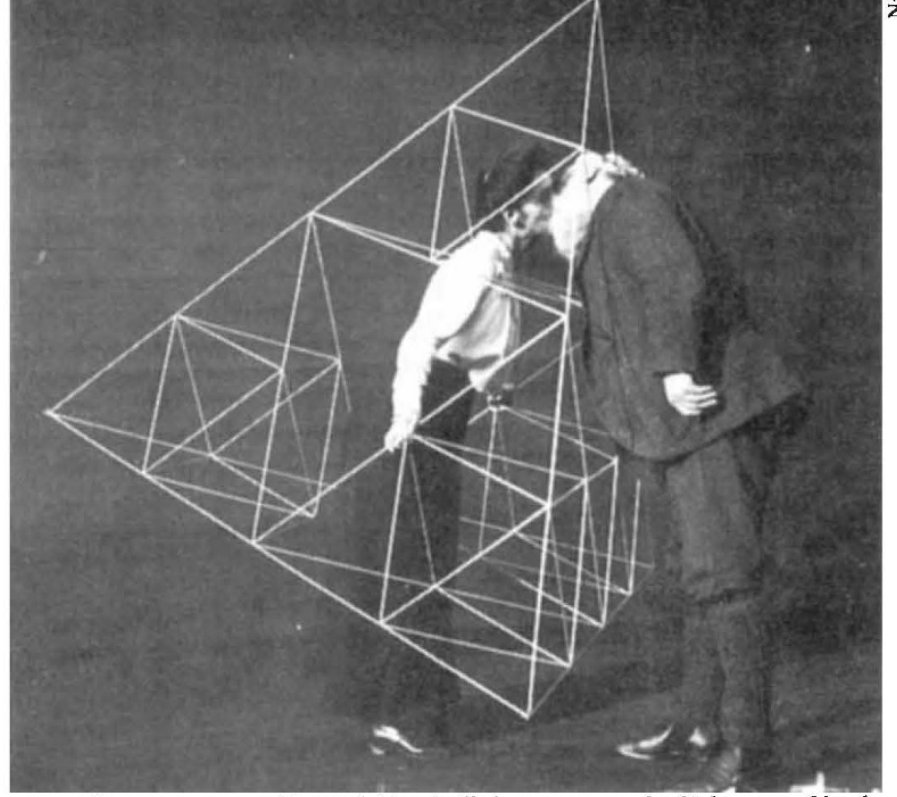

tions, refused advertisements for liquor, and also insisted that "Nothing of a partisan or controversial character is printed" and that "Only what is of a kindly nature is printed about any country or people, everything unpleasant or unkindly critical being avoided". This extreme conservatism might be construed as responsible journalism, and it was certainly good business (the Society today has subscribers in 170 different countries), but it sometimes had strange consequences. A 1949 article on the southern United States neither mentioned nor illustrated the black population, and the articles on Hitler's Germany and Stalin's Russia show the magazine at its anodyne worst. When, in 1977, realism was first introduced in features on Cuba, Harlem, Quebec and South Africa, the rumpus almost split the Society.

It is a measure of the book's quality that all these things are frankly discussed. Bryan was given the fullest cooperation by the Society, but he writes as an independent, albeit affectionate, outsider, and he has not produced a work of uncritical homage. Some people will read this book for the pleasure of its photographs and ragbag of facts. Others will appreciate that it also constitutes an important contribution to the history of science - not what scientists write about themselves, but science as perceived by the man in the street. The National Geographic Society has to be taken seriously. Its income is greater than the total science budget of many developing countries and, both as a patron of research and as an international opinion-former, it is an independent power in a world where high-level decisions on scientific policy are increasingly taken by politicians rather than by scientists weaves, in alternating chapters, the / smelled blood". At this point one realizes history of the Society (and the behind-the- that, after all, the text of National Geoscenes debates over ideology and editorial graphic articles does matter, and that policy), with thematic sections on, for (despite its international pretensions) the example, the Society's contribution magazine reflected, for most of its existo polar exploration, mountaineering, tence, the world view of small-town, archaeology, oceanography, aviation, white, Anglo-Saxon and Protestant space science and the development of America.

colour photography. These sections provide a fascinating trip down memory lane, but they also show the importance of the Society's archives for future historians and social scientists.

The Society's photographers recorded everything, from major news events (such as the Bikini hydrogen bomb explosion of 1954, the Columbia space launch of 1981 themselves. Worldwide, the Society has almost 11 million members, and many times that number read its magazine. That's a lot of voters.

Warwick Bray is Reader in Latin American Archaeology at the Institute of Archaeology, University College London, 31-34 Gordon Square, London WC1HOPY, UK.

This theme is taken up in the historical of the Grosvenor dynasty that ran the Society almost as a family business. The first Grosvenor laid down the principles which determined both the strengths and the weaknesses of the magazine for more than half a century. He demanded strict factual accuracy and abundant illustra-
In the wake of Colin Renfrew's new book Archaeology and Language (reviewed in Nature of 28 January), Edinburgh University Press has just produced a second edition of Renfrew's The Idea of Prehistory, first issued in 1962. The revised edition contains two new chapters by Glyn Daniel which consider developments with the advent of 'New Archaeology' and radio-carbon dating. The book costs $£ 19.50$. sections of the book, and in the story 